DOI:

\title{
Tasarımla Rekabet Avantajı: Türkiye'deki İşletmeler Üzerine Bir İnceleme
}

\author{
Sezin ERYILMAZ ${ }^{*}$ \\ ${ }^{1}$ T.C. Haliç Üniversitesi, Mimarlık Fakültesi / Endüstri Ürünleri Tasarımı Bölümü, \\ İstanbul, Türkiye \\ ORCID: 0000-0002-6034-5110
}

Geliş Tarihi: 14.02 .2020

*Sorumlu Yazar e mail: sezineryilmaz@halic.edu.tr Kabul Tarihi: 14.03.2020

Atıf/Citation: Eryılmaz, S. "Tasarımla Rekabet Avantajı: Türkiye'deki İşletmeler Üzerine Bir İnceleme” Haliç Üniversitesi Fen Bilimleri Dergisi 2020, 3/1: 85-107.

Araştırma Makalesi/ Research Article

\section{Özet}

Küresel rekabetin hızla arttığı günümüz koşullarında müşteri beklenti ve taleplerini karşılamanın yolu işletmelerin etkin bir tasarım stratejisi oluşturmasından geçmektedir. Bu bağlamda endüstri ürünleri tasarımı, işletmelerin rakiplerine karşı rekabet üstünlüğü elde etmesinde stratejik bir öneme sahiptir. Konu ile ilgili olarak yapılan bilimsel çalışmalarda işletme verileri ve rekabet edebilirlik arasındaki ilişkinin tasarım aracılığıyla gerçekleştiğine dikkat çekilmektedir. Bu kapsamda yapılan çalışmada tasarımın mobilya, otomotiv ana/yan sanayi, endüstriyel makine sanayinde faaliyet gösteren firmaların işletme verileri ve rekabet edebilirlikteki rolünün istatistiksel analizi yapılmış ve elde edilen bulgular değerlendirilmiştir. Çalışmada elde edilen veriler doğrultusunda endüstriyel tasarımın öneminin işletmelerde genel olarak anlaşılır olduğu fakat tasarım yönetimi kabiliyetinin yetersiz olduğu sonucuna varılmıştır.

Anahtar Kelimeler: Endüstriyel tasarım, Rekabet avantajı, Tasarım yönetimi, İş stratejisi

1 Bu makale Sezin Eryılmaz tarafından, Haliç Üniversitesi Fen Bilimleri Enstitüsü Endüstri Ürünleri Tasarımı Programı'nda, Prof. Önder Küçükerman danışmanlığında 2016 yılında tamamlanan "Endüstri Ürünleri Tasarımında İşletme Verilerinin Rolü ve Sistemleştirilmesi" adlı yüksek lisans tezinden üretilmiştir. 


\title{
Competitive Advantage by Design: A Study on Businesses in Turkey
}

\begin{abstract}
In today's rapidly increasing global competition conditions, the way of meeting customers' expectation and demands is through constructing an efficient creation strategy. In this context, the creation of industrial products has strategic importance for all businesses to get superiority over their competitors. In the research results of the related area the focal point is taken toward the relationship between data of businesses and competitiveness established by design. In light of this, the statistical anaylsis of the role of design on the proceeding data and compativeness of furniture, main/sub-automobile industry and industrial machine industry based companies is conducted and the results are evaluated. In line with research results, the importance of industrial design is generally acknowledged but the ability of management of design is found inadequate as a result.
\end{abstract}

Keywords: Industrial design, Competitive advantage, Design management, Bussiness Strategy

\section{Giriş}

Gelişen teknoloji ile birlikte küreselleşen dünyada, değişen hayat dinamikleri, tüketici talep ve ihtiyaçları üzerinde de sürekli değişikliklerin yaşanmasını sağlamaktadır. Yaşanan tüm bu gelişmeler doğrultusunda üretim, hizmet, pazarlama, servis, yönetim, gibi endüstriyel tasarım alanlarındaki tanımlamalar ve kapsamlarda da değişimler olduğu görülmektedir. Günümüzde tasarım süreci artık ürüne sadece fiziksel değerler atayan bir uğraş olmanın ötesinde, problem çözen, ürüne değer katan, yaşamı değiştiren, ekonomik gücü belirleyen, rekabet edilebilirliği sağlayan, duyarlılığı geliştiren ve etkileşim sağlayan bir strateji olarak geniş kitleler tarafindan kabul edilmektedir [1]. Dolayısıyla nihai işletmelerin sektörde hayatta kalabilmeleri, yeniliği yakalayabilmeleri ve değişimde sürekliliği elde edebilmelerindeki tek yolun bu stratejiyi ne kadar etkin bir şekilde kullanıp kullanmamalarına bağlı olduğu aşikârdır [2]. 
$\mathrm{Bu}$ çalışmanın amacı, endüstriyel tasarımın, işletme içerisindeki etkisinin ve yerinin ne olduğunu, işletme tarafından nasıl algıland1ğını, tasarımın işletme fonksiyonlarıyla ilişkisini, işletme performans verileri ile bağlantısını, tasarım sürecinde bu verilerin ne kadar etkili olduğu hakkında bilgi toplamaktır. Bu bilgilere ek olarak bu çalışma, Türkiye'deki işletmelerin tasarıma bakış açılarını öğrenmeyi, tasarımın işletmenin başarı ölçütlerine ne miktarda katkı sağladığını tespit etmeyi, bu ölçütlerin tasarımla bağlantısını belirlemeyi temel almaktadir.

\section{Materyal ve Metot}

$\mathrm{Bu}$ araştırmada alan araştırması verilerinin elde edilmesinde anket yöntemi kullanılmıştır, anket formu e-posta, telefon ve yüz yüze görüşme yoluyla uygulanmaya çalışılmıştır.

Araştırmanın evreninin \%39'unu İstanbul'da bulunan işletmeler oluştururken, \%34'ünü Ankara, \%12'sini Eskişehir, \%8'ini Kocaeli ve \%7sini Bursa ili paylaşmaktadır.

Anket formunun ilk kısmı işletmelerin genel bilgilerinden, ikinci kısmı ise 5'li Likert tipi ölçünün kullanıldığ 1 işletme-tasarım bağlantılarını ölçen maddeler olmak üzere iki ana kısımdan oluşmaktadır. Anket formunda yer alan soruların bir kısmı güvenilirlik ve geçerliliği kanıtlanmış olan literatürden derlenmekte olup, yeni soruların da oluşturulduğu bir düzen içinde ölçeklendirilmiştir.

Anket formunun ilk kısmını oluşturan genel bilgiler; işletme özelliklerine ait genel bilgiler, işletmenin bulunduğu şehri, işletmenin faaliyet alanını, yılını, işletmenin türünü ve ölçeğini, çalışan sayısını içermektedir. İkinci kısmını oluşturan tasarım işletme performansına yönelik sorular; ankete katılan işletmelerin endüstriyel tasarıma bakışını ölçen, ürün tasarım sürecinde dikkate aldıkları verileri belirleyen, tasarımın işletme başarı ölçütleriyle ilişkisini ölçen, tasarımda işletme performansının etkisini belirleyen, işletme kararlarında tasarımın önemini irdeleyen, rekabet edebilirliğin tasarımla bağlantısını 
aydınlatmaya çalışan soruları içermektedir. İşletmelerden bu soruları ilk bölümdeki sorulardan farklı olarak beşli Likert ölçekle (5 "kesinlikle katılıyorum", 4 "kat1lıyorum", 3"kısmen kat1lıyorum", 2 "kat11mıyorum, 1 "fikrim yok") değerlendirmeleri istenmiştir. Araştırmanın verileri SAP2000 adlı istatistik programı ile çözümlenmiştir. Ayrıca gereken durumlarda verilerin analizi ve grafik sunumları Excel programı yardımıyla yapılmıştır.

Endüstri ürünleri tasarımının işletme performansı üzerinde etkisini incelemek üzere otomotiv ana/yan sanayi, mobilya ve endüstriyel makine sanayide faaliyette bulunan işletmelerin verileri alınarak, analizin bulgularına erişilmiştir.

\subsection{Endüstriyel tasarım süreci}

Literatürde endüstriyel tasarım sürecine yönelik çeşitli tanımlamalar bulunmaktadır. Tasarım süreci, fikirleri bilgiye ve sürece dönüştürerek yeni bir ürünün gerçekleştirilmesi olarak tanımlanmaktadır [3]. Hollins ve Hollins [4] tasarım sürecini; yaratıcı bir iç süreç, harici bir üretim süreci, yönetim süreci ve bir planlama süreci olarak dört fonksiyonlu süreç olarak ifade etmiştir. Bruce ve Bessant [5] tasarım sürecinin üç temel aşamasını planlama, gelişim ve üretim-satış olarak değerlendirmektedir. Fikir ile başlayan başlangıç sürecinde, fizibilite çalışması yapılarak, işletme için bu tasarımın geri dönüşünün finansal açıdan iyi olup olamayacağına yönelik bir fizibilite raporu sunulur. Bu rapor doğrultusunda tasarımın tanımı yapılır. Gelişme aşamasında ise ürün ile ilgili detaylar belirlenerek prototip ve test aşamasından geçirilir. Bu aşamalardan sonra ürün, üretilebilir halini alır ve son olarak ürün üretilerek pazarlama aracilığgyla tüketicilere satışı sağlanır [5]. Küçükerman [6] da tasarım sürecini üç temel ana başlikta özetlemektedir. Birinci aşama gerekçeler ve hedefler, ikinci aşama ilkeler ve tanımlar, üçüncü aşama ise gerçek ürün süreci olarak ifade edilmektedir. İlk aşama hedeflerin açık biçimde tanımlanmasıyla başlar, ikinci aşama ürünün tanımlanması ve biçimlendirilmeye 
dönüşmesidir. Üçüncü aşamada ise gerçek ürün süreci başlar. Hedeflerin açık biçimde tanımlanmadığı birinci aşama genel hatlarıyla; tasarım çalışması yapılacak ürün için ilk belirlenenleri, tasarımın kuruluş açısından anlamı ve öneminin açıklığa kavuşmasını, müşteri beklenti ve eğilimlerini, üründen beklenen başarıların belirlenmesini içermektedir. İkinci aşama ön tasarım için ilkelerin belirlenmesini, ürünün kesin ilkelerinin tanımlanmasını, deneme amaçlı üretim sürecine geçişi kapsamaktadır. Son aşama ise, ürünün gerçek tasarımın ayrıntılarının kesinleştirilip onaylanmasını, teknik hazırlıkları, pazara giriş ve sonrasındaki süreçleri kapsamaktadır [6].

\section{2. Ürün tasarımında rekabet}

Rekabet edebilirlik, bir ekonominin serbest ticaret ve piyasa koşullarında, yerel ve uluslararası piyasaların taleplerini karşılayan mal ve hizmet üretebilme gücüne ne derece sahip olduğunu anlatan bir kavramdır [7]. Ekonomilerin rekabet edilebilirliği, üretim faktörlerinin etkin ve verimli kullanılmasıyla belirlenir. Ülkelerin yaşam standartları büyük ölçüde verimliliklerine dayalı olduğundan rekabet edebilirliğin de temel olarak dayandığı nokta verimliliktir [7]. Porter [8] da 'rekabet edebilirlik' kavramını, toplumun refahının yükseltilmesi kapsamında irdelemekte ve bu kavramı, verimliliği yükseltebilme becerisi olarak tanımlamaktadır. Bu rekabet edebilirlik yarışının tümüyle yenilikçi firmalar arasında yaşandığını, teknolojik yenilik yaratma yetkinliğinin verimliliği arttığını savunmaktadır [8].

\subsection{Tasarımla rekabet}

Günümüzde işletmelerin hayatta kalmaları ve büyümeleri önündeki en büyük engelin küresel alanda yoğunlaşmış rekabet politikaları olduğunu söylemek mümkündür. Bu yoğun rekabet ortamında mikro bazda işletmelerin, makro anlamda da ulusal ekonomilerin ayakta kalabilmeleri veya güçlenebilmeleri için iktisadi ve sosyal temelli çeşitli 
politika ve uygulamalar geliştirilmektedir. $\mathrm{Bu}$ politikaların başarılı olabilmeleri için, işletmelerin maliyet ve finansman odaklı çözüm arayışları dışında, pazarda sürekli rekabet avantajı sağlayacakları stratejiler geliştirmeleri gerekmektedir. Son dönemde çoğu sanayileşmiş ülkenin gündeminde olan ve temelleri 1950'li y1llara dayanan tasarım stratejileri; tasarımın etkin kullanımının ürüne katma değer sağlama ve rekabet avantajı elde etme üzerine odaklanmaktadır [9].

Tasarım kullanımının uluslararası rekabet gücüne etkisini açıkça ortaya koyması bakımından Dünya Ekonomik Forumu (WEF) tarafından yayınlanan Küresel Rekabet Gücü Raporları önemli bir kaynaktır. Rapor, tasarım kullanımının işletme girdisi olarak değerlendirildiği belirli ölçütleri içeren göstergeleri ele almaktadır. Bu rapora göre tasarım kullanımına ait yedi endeks belirlenmiş olup, bu endeksler ve puanlarının derecesi aşağıdaki gibidir. Endeks puanında ifade edilen 1 derecesi en düşük seviyeyi gösterirken, 7 derecesi en yüksek seviyeyi göstermektedir.

1. Ar-Ge harcamaları: Ülkedeki şirket sayısı (1= Ar-Ge harcamasinın olmaması, 7= Uluslararası seviyede Ar-Ge harcamasinın olmasi )

2. Rekabet gücü kaynağı: Ülkedeki şirketlerin uluslararası pazarda rekabet gücünün kaynağ1

(1 = Düşük maliyet ve yerel doğal kaynaklar, 7 = Yenilikçi ve orijinal ürünler ve süreçler)

3. Değer zinciri: Ülkedeki ihracat yapan işletmelerin ihraç ürünlerinin çeşitliliği

( 1 = Sadece üretim ve ham madde temelli, $7=$ Sadece üretim odaklı değil aynı zamanda ürün tasarımı, pazarlama, lojistik hizmeti ve satış sonrası hizmet bazlı)

4. İnovasyon kapasitesi: Ülkedeki teknoloji sahibi işletmelerin teknoloji yapisi

( 1 = Sadece yabancı şirketleri taklit etme veya lisans yoluyla elde edilen teknoloji yapısı, 7 = İşletmenin araştırmalarını kendisinin yönetip, ürün ve süreçlerine kendisinin öncülük etmesi) 
5. Üretim yapısı: Ülkedeki işletmelerin üretim süreçlerinin yapısı (1 = Eski üretim teknolojilerinin kullanımı, $7=$ En etkili, en verimli süreç teknolojilerinin kullanımı)

6. Pazarlama gücü: Ülkedeki işletmelerin pazarlama gücü ( 1 = Sınırlı ve ilkel şekilde, 7 = Yoğun ve en ileri araç ve tekniklerinin kullanımı ile)

7. Müşteri memnuniyetinin derecesi: Ülkedeki işletmelerin müşteriye davranışları

(1 = Müşteri memnuniyetinin hiçbir şekilde sağlanamaması, 7

= Yüksek oranda müşteri beklentisini karşılaması ve bağlılığ1nın sağlanabilmesi)

Tasarımın kullanımına ilişkin endeksler genel rekabet gücü sıralamasıyla karşılaştırıldığında, rekabet gücü ile tasarım kullanımı arasında güçlü bir bağlantı olduğu görülmektedir [9].

\subsection{Rekabette inovasyon faktörü}

Ülkelerin uluslararası rekabette katma değer odaklı tasarım stratejileri ve ihracat hedefli planları, tasarım kavramını ürünleşmeye giden yolda daha önemli bir hâle sokmaktadır. 2005 yılında Ekonomik Kalkınma ve İş birliği Örgütü (Organisation for Economic Co-operation and Development) OECD'nin (OECD-Eurostat Oslo Manual) bilim ve teknolojiden oluşan eski inovasyon tanımını, ürün tasarımını da kapsayacak şekilde genişletmesi, tasarımın küresel rekabete giden yolda vazgeçilmez bir unsur olduğunu kanıtlamaktadır.

Günümüzde işletmeler için inovasyon kavramı, yeni ürün, kavram veya bilinen prensiplerin "yeniden" ekonomik katma değer yaratacak bir şekilde uygulanması olarak tanımlanmaktadır [1]. Bu tanım;

1. Üretimde fonksiyonel değişimler yapma,

2. Pazara yeni malların girmesi (arz fonksiyon artış1),

3. Pazarda yeni mamullerin uygulanması, sosyal reform olarak alt bileşenlere ayrılabilir [1]. 
Schumpeter [10], kalkınmanın itici gücü olarak tanımladığı inovasyon kavramını dört farklı kategoride değerlendirmektedir. Bunlar:

- Yeni bir ürün/ hizmeti tanımlamak,

- Yeni bir üretim yöntemi/süreç oluşturmak,

- Yeni örgütlenme biçimi,

- Yeni bir pazarlama yöntemi,

Bu sinıflandırmaya günümüzde "hizmet" kavramının da eklenmesi ile inovasyon kavramı beş farklı başlık altında değerlendirilmektedir [1].

\section{5. Ürün tasarımının firma performansına etkisi}

Bir işletme için ürün tasarım etkinliği, işletmenin bulunduğu sektöre göre değişiklik gösterse de günümüzde küresel pazarda yer almak ve rekabet edebilmek ülke ekonomisine katma değer sağlama adına önem arz etmektedir. Gelişen teknoloji ile birlikte, üretilen ürünlerin kaliteleri bir standarda oturtulunca, küresel pazarda fark yaratmanın yegâne unsuru tasarım olmuştur. Amerika Birleşik Devletleri (ABD) ve Avrupa'daki üretim firmalarının tasarım bütçelerini $\% 8$ 'den \%20'ye yükseltmeleri, Ford'un 1990 yılından beri tasarıma ayırdığı bütçenin, eskiye göre iki katı miktarda olması [11; 12] bunu kanıtlar niteliktedir.

Üretim maliyetleri açısından değerlendirildiğinde, toplam üretim maliyetleri içinde etkisi sadece $\% 5$ 'ler düzeyinde kalan bir normal tasarım sürecinin, ürünün pazar değeri üzerindeki ölçülebilir etkisinin \% 70'lere vardığı gerçeği [1] ürün tasarımının, firmanın performansını ne ölçüde etkilediğini gözler önüne sermektedir.

Ürün tasarımının işletme performansı üzerinde etkisinin kapsamı geniştir. Bu kapsam süreç sonuçları, müşteri sonuçları, finansal sonuçlar ve direkt olmayan sonuçlar olarak dört başlıkta incelenebilir [2]. Süreç sonuçları zaman, kalite, maliyet kapsamında ele alınırken, müşteri sonuçları; müşterinin memnuniyeti bu memnuniyetin dolaylı olarak sağladığı sonuçlar olan pazar payının arttırılması, müşteri kârlılığ1 gibi sonuçlar olarak ele alınmaktadır. Finansal sonuçlar ise, işletmenin 
nakit akışı, kârı, yatırımın geri dönüşü, hisse senedi fiyatı şeklinde tanımlanabilir. Süreç sonuçlarının zaman, kalite ve maliyete etkileri, müşteri sonuçlarını etkilemektedir, müşteri sonuçlarının çıktısı olan memnuniyet, kazanım, pazar payı, müşteri kârlılığı finansal sonuçları etkilemekte, dolayısıyla bu finansal sonuçlar kârlılık, nakit akışı, net satışlar gibi değerler hakkında doğru bilginin alınmasını sağlamaktadir.

Tasarımın kalitesi, organizasyon ve yönetim olarak girdi kapsamında değerlendirilmekte, işletmenin başarı ölçütlerini yansıtan finansal veriler, uygulamalar ve maliyetler, tasarımın kalitesi, organizasyonu ve yönetimi ile şekillenerek çıktılara dönüşmektedir. Ticari çıktıların etkin şekilde yönetilmesi ve iyileştirilmesi durumu söz konusu olduğunda ise şekil 1'e göre tasarımın yönetilmesi ve iyileştirilmesi gerekmektedir.

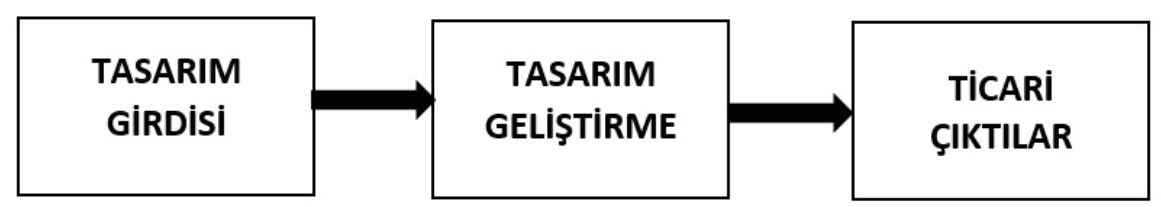

$\begin{array}{lll}\text { Tasarım danışmanlığının kalitesi } & \text { Tasarım Organizasyonu ve Yönetimi } & \text { Uygulama } \\ \text {-Şirket içi } & \text {-Tutum } & \text { Finansal veriler } \\ \text {-Şirket dışı } & \text {-Tecrübe } & \text {-Satışlar } \\ & & - \text { Kar } \\ & & \text { - Pazar büyüklüğü }\end{array}$

Şekil 1. Tasarımın Ticari Etkileri [13]

Şekil 2 [14] de ise inovasyon ve araştırma ve geliştirme (ar-ge)'nin ürün tasarım sürecinde, verimliliğe ve işletmenin ticari performansına hangi bağlantılarla katkı sağladığı görülmektedir. Şekil 2'de yedi ayrı bileşen (ar-ge, inovasyon, tasarım, verimlilik, yaratıcılık, yaratıcı ortam, ticari performans) ve bu bileșenlerin kendi aralarında bağlantılı 
olduğu bileşen ya da bileşenler okla gösterilmiştir. Şekle göre inovasyon, tasarımla bağlantılı olmakla birlikte ar-ge'nin de bağlantısını içermektedir. Ticari performansa giden bağlantının ise sadece tasarım ve yaratıcılıkla olabildiği kadar, ar-ge inovasyonla, tasarım ve verimlilik bağlantılarının birleşimiyle de sağlandığı görülmektedir.

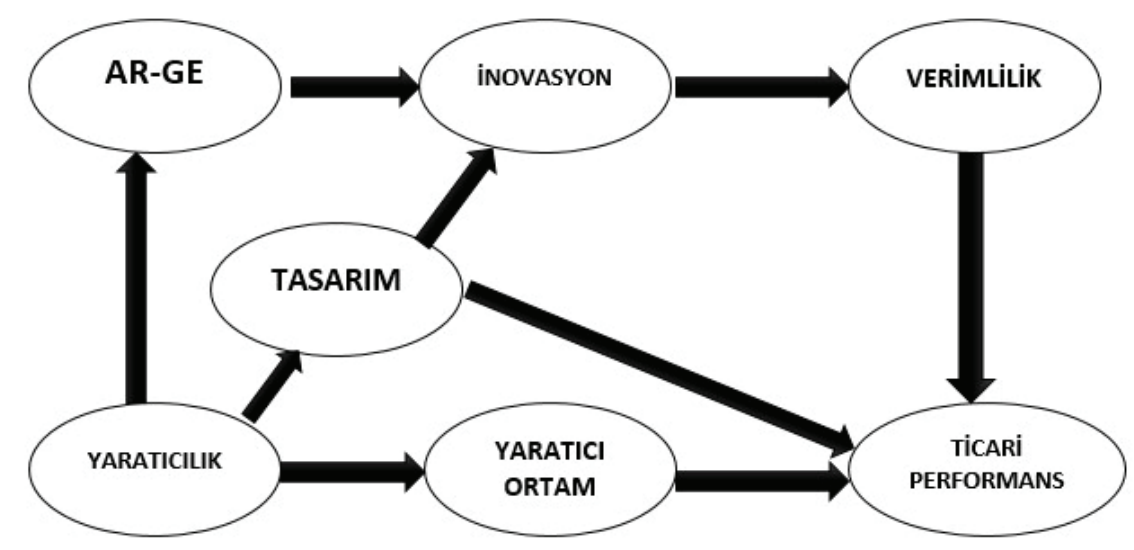

Şekil 2. Firmanın Ticari Performansı Arasındaki Bağlantılar [14]

\subsection{Firma performansında tasarım-verimlilik yaklaşımı}

İşletme açısından çıktıların, girdilere oranı olarak tanımlanan verimlilik, bir diğer yaklaşımla tasarım girdilerinin çıktılara ne oranda dönüştügüunü gösteren ölçüttür. Firma performansını ölçerken üretilen mal ve hizmetler çıktı değerini alırken, kullanılan kaynaklar ve maliyetler girdi olarak nitelendirilmektedir. İyi tasarımın firmanın verimliliğini arttırdığını gösteren birçok araştırmanın yanı sıra, verimliliği inovasyonla bağdaştırıp işletmenin performans analizini yapan da birçok çalışma bulunmaktadır $[15 ; 16 ; 17 ; 18]$.

İnovasyon ve verimliliği bağdaştıran Griliches [15] 1965-1984 yılları arasında İngiliz endüstrisinde Ar-Ge'ye yapılan yatırımların y1llık \%20-\%25'inin geri döndüğünün sonuçlarına vararak, inovasyonun firma ve ulusal verimlilikteki büyüme için pozitif bir etkisi olduğunu kanıtlamıştır [15]. 
Walsh, Roy vd. [16] yaptıkları araştırmanın sonuçlarına göre ise inovasyon, üretim sürecini etkileyerek malzeme kullanımında fark edilir azalma ve üretimde enerji tasarrufu sağlayarak, verimliliği büyük ölçüde arttırmıştır [16]. Benzer bir diğer çalışma ise Hertenstein, Platt ve Veryzer'in [17] 4 ayrı endüstriye yönelik 12 farklı firma performans faktörünün irdelendiği çalışmadır. Bu araştırmaya göre, dört sektörde de tasarımın niteliği arttıkça, firmanın verimliliği artmaktadır. Tasarım, verimlilik ve firma performansı ile pozitif bir ilișki içindedir [17].

İşletmenin başarısının ölçütü olan verimlilik, işletmenin yaptığı Ar-Ge çalışmalarının niteliğinin derecesine göre artıp ya da azalmaktadır [18]. İşletme Ar-Ge yatırımına ne kadar önem veriyorsa verimlilik o kadar artarken, Ar-Ge yatırımının zayıf olduğu bir işletmede verimlilik, aynı endüstride yatırımın fazla olduğu işletmeye göre azalmaktadir.

\subsection{Firma performansında tasarım-karlılık yaklaşımı}

Kârlılık işletmenin en önemli başarı ölçütlerinden biri olup, işletmenin var olma sebeplerinden biridir. Tasarım faktörünün satışları arttırdığını gösteren veriler mevcut olmakla beraber, satışların artması, işletmenin finansal performansını etkileyen bir unsurdur fakat tek başına kârlılığı arttıran bir unsur değildir. Kârlılığın artması için işletmenin satışlarının, işletmenin giderlerine göre daha yüksek olması gerekmektedir [17].

Yapılan çalışmalar, tasarımla işletmenin kârlılığ 1 arasında bir ilişki olduğunu göstermektedir $[10 ; 11 ; 16 ; 17 ; 18]$. Tasarımın önemi konusunda farkındalık sahibi olan firmalarla, bu olguyu önemsemeyen firmalar karşılaştırılarak, tasarımının önemini fark edip, ağırlık veren firmaların, yüksek kârlılık oranına sahip olduğu hesaplanmıştır. Ayrıca tasarımın fiyat, talep, ürün maliyeti ve gelir? giderleri etkileyerek yüksek kâr oranı sağladığı ve bu firmaların yönetimde de daha başarılı olduğu gözlenmiştir [19]. 
Hertenstein vd.[17] dört farklı sanayide (mobilya, elektronik, bilgisayar, araç) yaptıkları çalışma on iki faktör üzerinden incelenmiştir, buna göre de iyi tasarım daha yüksek satış getirisi getirmektedir [17].

Bir başka çalışma Srivasta vd. [20] çalışmasıdır, bu çalışmaya göre tasarım firmanın pazar değerini belirleyerek, kârlılığı arttırmaktadır [20]. Guo [21] tarafından aynı endüstride ödül alan 577 tasarımla, ödül kazanmayan 524 tasarımın finansal performansının (satış, maliyet, kârlılık, büyüme hızı, pazar payı üzerinden) karşılaştırılması yapılarak; iyi tasarımın kârlılığı arttırdığı kadar, firmanın büyümesinde de katkısının olduğu kanıtlanmıştır [21] .

\subsection{Firma performansında tasarım-inovasyon, ar-ge yaklaşımı}

Tasarımda inovasyonun rekabette anahtar rolü oynadığ yapılan birçok çalışmada kanıtlanmaktadır [22; 23; 24; 25]. İnovasyon firma büyümesi ile pozitif bir ilişki içindedir, yükselen bir pazarda inovasyona ve tasarıma yaklaşım olumlu iken, küçülmekte olan pazarda bu yaklaşım olumsuzdur. Roy, Riedel ve Potter tarafından yapılan çalışmada [22] 42 endüstri firması ile yaptıkları görüşmelerde, 16'sının inovasyonun şirketlerinde büyük önem kapladığını, \%73 oranında üretim maliyetlerini düşürdüğü tespit edilmiştir. Hsu [23] tarafından yapılan araştırmada ise inovasyon stratejisinin, tasarım stratejisiyle ve tasarım özelliği ile pozitif bir ilişki içinde olduğu kanıtlanmıştır [23].

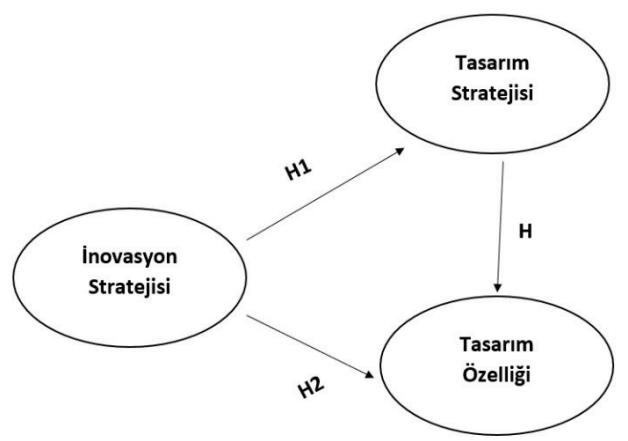

Şekil 3. İnovasyon İlişsileri [23] 
Choi ve Williams [24] tarafindan 897 firma üzerinden yapılan araştırmada inovasyon ve tasarımın, firmanın bulunduğu yerdeki koşullarına bağlı olarak geliştiğini, performansın da buna bağlı olduğunu kanıtlayan bir çalışma gerçekleştirilmiştir [24].

Tasarımda inovasyon firmanın teknolojiyi kullanma kapasitesine bağlı olarak gelişim göstermekte, Gao, Liu, Song, ve Zheng'in 315 firma bazında yapılan çalışmasına göre [25] teknoloji seviyesi arttıkça, inovasyon ve ar- ge çalışmalarına ayrılan zaman arttıkça rekabet edebilirlik artmakta, bunun sonucunda firmanın finansal performans1 yükselmektedir. Firmanın sahip olduğu teknoloji kapasitesinin yapılan ar-ge ve inovasyonla pozitif bir ilişki içinde olduğu yapılan araştırma sonucunda bulunmuştur [25].

\subsection{Firma performansında tasarım-müşteri memnuniyeti yaklaşımı}

Literatürde tüketicinin bir ürünü diğerine göre tercih etme sebebinin arkasında yatan tasarım özelliklerinin, kullanıcı memnuniyeti ile paralel gittiğini gösteren birçok araştırma bulunmaktadır $[13 ; 16 ; 17 ; 18 ; 22 ; 26]$. Firmalar performans geliştirme yolunda temelde iki yöntemle hareket etmektedirler, bunların birincisi pazar payını arttırma yoluna gitmek, ikincisi ise müşteri kârlılığını arttırmaktır. Müşteri memnuniyeti ise bu iki yöntemde de önemli rol oynayan bir faktördür [26].

Müşteri memnuniyetinin sağlanması için tasarımın ürün performansı, güvenlik, kolay kullanım gibi kısa vadeli sonuçlar üzerinden ya da tasarımın dayanıklılık, uzun ömürlülük, servis ağı gibi uzun vadeli sonuçlar üzerinden ele alınması gerekmektedir. Diğer faktörler ise, marka değeri, pazar payı, müşteri geri bildirimleri, satın alma payının artışı, kalite değerlendirmeleri, yorumlar, net satışların satış sonrasındaki payı, tasarım tercih araştırmaları, müşteri başına düşen ürün sayısını arttırmak vb. sıralanabilir [13].

Araştırmalar tasarımın süreç sonuçlarının, ürün özelliklerinin müşteri memnuniyetini etkilediği, bu memnuniyetin tasarımın 
inovatif olması, estetik, kullanışlı olması, işlevsel olması gibi işlevlerin iş birliği sonucuyla şekillendiğini göstermiştir. İyi tasarım, tasarımın niteliğini arttıran ürün özellikleri, müşterinin üründen beklentisini karşılamakta ve müşterinin memnuniyetini arttırmaktadır. Artan müşteri memnuniyeti firmanın pazar payını, kârlıl1ğını, inovasyon ve ar-ge'ye yapılan yatırımı pozitif olarak etkilemektedir [26].

\section{Bulgular ve Tartışma}

\section{1. Örnekleme süreci}

Araştırmada kullanılacak olan örnekleme büyüklük bakımından kavramsal modeldeki değişkenlerin genelleştirilebilmesini mümkün kılacak şekilde seçilmiştir. 127 işletme anket sorularının tamamını cevaplamıştır. Geri dönüşüm oranı \%24,2 civarındadır. Anketi cevaplayan firmaların; 44'ü endüstriyel makine (\%34,66), 40'1 mobilya (\%31,49), 43 'ü otomotiv ana ve yan sanayi $(\% 33,85)$ sektöründedir. Araştırmaya katılan işletmelerin faaliyet alanı, işletmenin türü, ölçeği, faaliyet yılları, çalışan sayıları, anketi cevaplayanların unvanlarının sayı ve yüzdelik dağılımlarına at bilgiler Tablo 1'de verilmiştir. Tablo 1'e göre araştırmaya katılan işletmelerin \%31,49'u mobilya sektöründen, \%34,66's1 endüstriyel makine, $\% 33,85$ 'i otomotiv ve yan sanayi sektöründen oluşmaktadır. İşletmelerin \%14,18'i limited olup, \%85,82'si anonimdir. Çalışan sayısı 50'nin altında olan işletme sayısı \% 54,4 iken, 50 'den fazla olan \%45,6'dır. Anketi dolduran işletmelerin \%33,10'u alanında yirmi seneden fazla faaliyet gösterirken, \%69,9'unun faaliyet senesi yirmi seneden azdır. Anket cevaplayan kişilerin unvanlarına baktığımızda \%21,25'inin genel müdür, \%25,19'unun işletme müdürü, \%36,22'sinin ise işletme sahibi tarafından cevaplandığ1 görülmektedir (Tablo 1). 
Tablo 1. Genel Bilgiler

\begin{tabular}{lll} 
Faaliyette Bulunan Sektör & Sayı & Yüzde \\
\hline Mobilya & 40 & 31,49 \\
Endüstriyel makine & 44 & 34,66 \\
Otomotiv ve Yan sanayi & 43 & 33,85 \\
\hline Toplam & 127 & 100 \\
& & \\
Çalışan sayısı & Sayı & Yüzde \\
\hline $0-9$ & - & - \\
$10-50$ & 69 & 54,4 \\
$51-200$ & 58 & 45,6 \\
$200+$ & - & - \\
\hline Toplam & 127 & 100
\end{tabular}

\begin{tabular}{llc}
$\begin{array}{l}\text { Anketi Cevaplayanların } \\
\text { Unvanları }\end{array}$ & Sayı & Yüzde \\
\hline Genel Müdür & 27 & 21,25 \\
İşletme Müdürü & 32 & 25,19 \\
İşletme Sahibi & 46 & 36,22 \\
Diğer & 22 & 17,34 \\
\hline Toplam & 127 & 100
\end{tabular}

\begin{tabular}{lll} 
İşletme Türü & Sayı & Yüzde \\
\hline Şahıs & - & - \\
Limited & 27 & 14,18 \\
Anonim & 109 & 85,82 \\
\hline Toplam & 127 & 100
\end{tabular}

\subsection{Veri toplama aracının güvenliği}

Araştırmanın anket formunda bulunan soruların güvenilirliğinin değerlendirilmesinde Cronbach Alfa katsayısından yararlanılmıştır. Cronbach alfa katsayısının 0.70 'den büyük olması değerlendirmenin güvenilir olduğunu göstermektedir [27]. 


\subsection{Araştırmanın analizi}

Çalışma kapsamında elde edilen veriler değerlendirildiğinde (Tablo 2) $\% 88,5$ kabulle farklılaşmaya giden yolun tasarımdan geçtiği işletmeler tarafından kabul görülmektedir, \%80,1 yüzdelik oranla tasarımın müşteri taleplerine göre şekillenir önermesinin ikinci sırada olmas1, tasarımda farklılaşmaya giden yolun müşteri taleplerini göz önüne alarak değerlendirilebilmesi sonucu çıkarılabilir. Tasarımın problem çözmesi önermesi üçüncü, firmanın imajına katkı sağlaması \%69 oranla dördüncü sırada yer almaktadır. Bu durum, tasarımda yaratılan farkın, işletmenin imajına da katkı sağladığı ankete katılan işletmeler tarafından anlaşıldığını gözler önüne sermektedir. En düşük oranı \%44'le endüstriyel tasarım rakipleri kopyalamaktır önermesi almıştır (Tablo 2, E2). Bu sonuca göre işletmeler tarafindan rekabete giden yolun tasarım kopyalamaktan geçmediği, bu yolun tasarımda farklılaşma olarak tanımlandığı sonuçların bütününden anlaşılmaktadır.

Tablo 2. Endüstriyel Tasarım Tanım Analiz Sonuçları

\begin{tabular}{|l|l|l|l|l|l|}
\hline A.Endüstriyel Tasarım Tanımı & $\begin{array}{l}\text { Kesinlikle } \\
\text { Katılıyorum }\end{array}$ & Katılıyorum & $\begin{array}{l}\text { Kısmen } \\
\text { Katılıyorum }\end{array}$ & Katılmıyorum & Fikrim Yok \\
\hline E1.Endüstriyel tasarım problem çözer. & $\% 35$ & $\% 37$ & $\% 15$ & $\% 13$ & - \\
\hline E2.Endüstriyel tasarım rakipleri kopyalamaktır. & $\% 7$ & $\% 37$ & $\% 45$ & $\% 11$ & - \\
\hline E3.Endüstriyel tasarım pazar payını arttrır. & $\% 12,3$ & $\% 38,5$ & $\% 34,9$ & $\% 12,3$ & $\% 2$ \\
\hline E4.Endüstriyel tasarım maliyeti azaltır. & $\% 23,1$ & $\% 30.4$ & $\% 35.5$ & $\% 9.7$ & $\% 1,3$ \\
\hline E5.Endüstriyel tasarım dış görünüştür. & $\% 26$ & $\% 42,1$ & $\% 27,7$ & $\% 4,2$ & - \\
\hline E6.Endüstriyel tasarım müşteri taleplerine göre şekillenir. & $\% 34,3$ & $\% 45,8$ & $\% 15,4$ & $\% 4,5$ & - \\
\hline E7.Endüstriyel tasarım üretimde sıkıntıları giderir. & $\% 11,9$ & $\% 34,6$ & $\% 36,8$ & $\% 16,7$ & - \\
\hline E8.Endüstriyel tasarım fark yaratıı & $\% 56,8$ & $\% 31,7$ & $\% 11,5$ & - & - \\
\hline E9.Endüstriyel tasarım gereksizdir. & - & $\% 3.1$ & $\% 4.2$ & $\% 45,4$ & $\% 47.3$ \\
\hline E10.Endüstriyel tasarım firma imajına katkı sağlar & $\% 31,8$ & $\% 37,3$ & $\% 24,8$ & $\% 6,1$ & - \\
\hline
\end{tabular}

Tablo 3 'te verilen firmaların endüstriyel ürün tasarımında önem verdikleri ölçütlere bakıldığgnda (Kesinlikle Katılıyorum + Katılıyorum) \%88.9 yüzdelik oranıyla ürün tasarımında maliyetin göz önünde bulundurulan en önemli faktör olduğu ortaya çıkmaktadır (Tablo 3, B2). \%88,8 oranla hemen arkasından gelen satılabilirliği, maliyetle birlikte bütünleştirildiğinde az maliyetle, çok satılan ürün yapma kıstası işletmelerin sektör gözetmeksizin en önemli hedeflerinin arasında 
yer aldığg sonucu çıkarılabilir (Tablo 3; B4). İhracat potansiyelinin önemli bir yüzde alması, işletmenin rakiplerine karşı üstünlügüüne giden yolun işletmenin ihracat potansiyelini arttırması olarak değerlendirebilir. Tasarımın tanımı sorusunda olduğu gibi bu soruda da müşteri taleplerinin öne çıkması bu faktörün işletmeler için tasarımda ne kadar öne çıktığını göstermesi bakımından önemlidir. İnovasyon ve geri dönüşümle ilgili yüzdelerin düşük çıkması, işletmeler tarafından bu konuda bir farkındalığın oluşmaması olarak yorumlanabilir.

Tablo 3. Ürün Tasarımında Önem Analiz Sonuçları

\begin{tabular}{|l|l|l|l|l|l|}
\hline B. Ürün Tasarımında Önem & $\begin{array}{l}\text { Kesinlikle } \\
\text { Katılıorum }\end{array}$ & Katılıyorum & Kısmen Katılıyorum & Katılmıyorum & Fikrim Yok \\
\hline B1.Ürün tasarımında malzeme seçimi önemlidir. & $\% 32,6$ & $\% 34,7$ & $\% 12,3$ & $\% 20,4$ & - \\
\hline B2.Ürün tasarımında maliyet önemlidir. & $\% 37,8$ & $\% 51,10$ & $\% 11,1$ & - & - \\
\hline B3.Ürün tasarımında üretime uygunluk önemlidir. & $\% 23,6$ & $\% 43,1$ & $\% 30,3$ & - & - \\
\hline B4.Ürün tasarımında satılabilirlik önemlidir. & $\% 45,6$ & $\% 43,2$ & $\% 11,2$ & - & - \\
\hline B5.Ürün tasarımında müşteri talepleri önemlidir & $\% 31,5$ & $\% 43,9$ & $\% 21,3$ & $\% 3,3$ & - \\
\hline B6.Ürün tasarımında rakiplere üstünlük önemlidir. & $\% 45,9$ & $\% 38,6$ & $\% 14,6$ & $\% 0,9$ & $\%$ \\
\hline B7.Ürün tasarımında inovasyon (yenilik) önemlidir. & $\% 23,7$ & $\% 34,2$ & $\% 36.9$ & $\% 2.2$ & $\% 3$ \\
\hline B8.Ürün tasarımında ihracat potansiyeli önemlidir. & $\% 34,7$ & $\% 53,8$ & $\% 10,2$ & $\% 1,3$ & - \\
\hline B9.Ürün tasarımında basitlik önemlidir. & $\% 21,7$ & $\% 24,9$ & $\% 34,5$ & $\% 13,4$ & $\% 5,5$ \\
\hline B10.Ürün tasarımında geri dönüşüm önemlidir. & $\% 18,7$ & $\% 39,6$ & $\% 37,6$ & $\% 3,2$ & $\% 0,9$ \\
\hline
\end{tabular}

Tablo 4. İşletme Başarı Ölçütleri Analiz Sonuçları

\begin{tabular}{|l|l|l|l|l|l|}
\hline C.İşletme Başarı Ölçütleri & $\begin{array}{l}\text { Kesinlikle } \\
\text { Katılıyorum }\end{array}$ & Katılıyorum & $\begin{array}{l}\text { Kısmen } \\
\text { Katılıyorum }\end{array}$ & Katılmıyorum & Fikrim Yok \\
\hline C1.Tasarım işletmenin karlıı̆ı üzerinde etkilidir & $\% 50,2$ & $\% 34,5$ & $\% 13,3$ & $\% 2$ & - \\
\hline C2.Tasarım işletmenin verimliliği üzerinde etkilidir. & $\% 37,8$ & $\% 31,7$ & $\% 23,3$ & $\% 7,2$ & - \\
\hline C3.Tasarım işletmenin ekonomikliği üzerinde etkilidir. & $\% 45$ & $\% 32,3$ & $\% 11,4$ & $\% 11,3$ & - \\
\hline C4.Tasarım işletmenin etkinliği üzerinde etkilidir. & $\% 23,6$ & $\% 34,7$ & $\% 36,8$ & $\% 4,9$ & - \\
\hline
\end{tabular}

Tablo 4'de verilen işletme başarı ölçütleri değerlendirildiğinde tasarımda dört başarı ölçütünün de işletmeler tarafından önem arz ettiği her birinin (Kesinlikle Katılıyorum + Katılıyorum) yüzdelerinin elliden fazla olması ile açıklanabilir. En fazla yüzdeyi \%84,7 (Kesinlikle Katılıyorum + Katılıyorum) payla tasarımın işletmenin kârlıl1ğını etkilediği önerme kapsamaktadır? . Bunu ekonomikliği ve verimliliği üzerindeki etkileri takip etmektedir. En düşük yüzdeyi ise \%58,3 (Kesinlikle Katılıyorum + Katılıyorum) oranla tasarımın işletmenin 
üzerindeki etkinliği önermesi almaktadır. Tüm başarı ölçütlerinin tasarımla bağlantısının yüksek çıkması, işletmelerin başarıya giden yolun tasarımla oluştuğunu anlamalarının yatmakta olduğu sonucu çıkarilabilir (Tablo 4).

Tasarım ve işletme performans göstergeleri arasındaki ilişkilere yönelik elde edilen sonuçlar Tablo 5'te verilmiştir. Bu sonuçlara göre, en fazlaya yüzdeye sahip (Kesinlikle Katılıyorum + Katılıyorum) önerme \%84 ile tasarım rekabet edebilirlikte etkilidir şeklindedir (Tablo 5). Bu sonuca göre rekabet edebilirlik düzeyi artınca, pazar payı, satış ve kârlılığın da arttığı sonucunu çıkarmak mümkündür. Literatürde elde edilen bu sonucu destekleyen benzer çalışmalar da bulunmaktadır $[15 ; 16: 17 ; 18 ; 19 ; 20 ; 21]$. Müşteri memnuniyetinin önemi bu soruda da ilk beş faktörün arasına girmiştir. Buna göre işletmenin finansal performansında müşteri memnuniyetinin önemli olduğunun sonucu ortaya konulabilmektedir.

Tablo 5. İşletme Performansı Analiz Sonuçları

\begin{tabular}{|l|l|l|l|l|l|}
\hline D.İ̧̧letme Performansı & $\begin{array}{l}\text { Kesinlikle } \\
\text { Katılıyorum }\end{array}$ & Katılıyorum & $\begin{array}{l}\text { Kısmen } \\
\text { Katııyorum }\end{array}$ & Katılmıyorum & Fikrim Yok \\
\hline D1.Tasarım pazar payındaki artışta etkilidir. & $\% 34,2$ & $\% 42$ & $\% 16,8$ & $\% 7$ & - \\
\hline D2.Tasarım satışların artmasında etkilidir. & $\% 32,1$ & $\% 45,7$ & $\% 12,6$ & $\% 9,6$ & - \\
\hline D3.Tasarım ihracat payının artışında etkilidir. & $\% 31$ & $\% 23$ & $\% 25,4$ & $\% 10$ & $\% 10,6$ \\
\hline D4.Tasarım ürün kalitesinin artışında etkilidir. & $\% 23,6$ & $\% 32,3$ & $\% 28,9$ & $\% 15,2$ & - \\
\hline D5.Tasarım verimlilik artışında etkilidir. & $\% 34,8$ & $\% 39,3$ & $\% 25,9$ & - & - \\
\hline D6.Tasarım karlıı̆ın artışında etkilidir. & $\% 45,6$ & $\% 32,3$ & $\% 11,6$ & $\% 10,5$ & - \\
\hline D7.Tasarım müşteri memnuniyetinde etkilidir. & $\% 34,9$ & $\% 45,7$ & $\% 10,3$ & $\% 9,1$ & - \\
\hline D8.Tasarım rekabet edebilirlikte etkilidir. & $\% 41,7$ & $\% 42,3$ & $\% 12,8$ & $\% 3,2$ & - \\
\hline
\end{tabular}

Tablo 6, araştırma anketinin tasarımın işletmenin stratejik kararlarındaki yerinin önemini ve rakamsal tespitini ölçmek için sorulan bölümünün sonuçlarını göstermektedir. Tablo 6 değerlendirildiğinde en yüksek yüzdenin (Kesinlikle Katılıyorum + Katılıyorum) \%84,7 ile "İşletme Sahibinin Kararının Önemi” olduğu tespit edilmiştir (Tablo 6, E6). Elde edilen bu veri doğrultusunda anketi cevaplayan işletmelerin çoğunun aile şirketi olduğu ve dolayısıyla kurumsallaşma sürecine girememelerinden kaynaklanmış olabileceği sonucunu çıkarmak mümkündür. Rakiplerinin faaliyetleri, işletmenin kararlarında 
(Kesinlikle Katılıyorum + Katılıyorum) \%77,9 oranında etkili olduğu anket sonucuna göre çıkmıştır (Tablo 6, E4). Pazar dinamikleri ve işletmenin geçmişi karar almada sıralamanın diğer önermeleridir. En düşük önerme \% 41,4 oranıyla tasarımın işletme kararlarında etkili olduğu önermedir (Tablo 6, E1). Bu önermenin diğer önermelere göre oldukça düşük çıkması, ankete katılan işletmelerin tasarımı karar almada stratejik bir unsur olarak kullanmamalarının sonucu olarak değerlendirilebilir.

Tablo 6. İşletme Kararları Analiz Sonuçları

\begin{tabular}{|c|c|c|c|c|c|}
\hline E.İşletme Kararları & $\begin{array}{l}\text { Kesinlikle } \\
\text { Katılıyorum }\end{array}$ & Katılıyorum & $\begin{array}{l}\text { Kısmen } \\
\text { Katılıyorum }\end{array}$ & Katılmıyorum & Fikrim Yok \\
\hline E1. İșletme kararlarında tasarım önemlidir. & $\% 9,4$ & $\% 32$ & $\% 42$ & $\% 13,5$ & $\% 3,1$ \\
\hline E2.Işletme kararlarında işletmenin geçmişi önemlidir. & $\% 32$ & $\% 34$ & $\% 23,7$ & $\% 10,3$ & - \\
\hline E3.Işletme kararlarında pazar dinamikleri önemlidir. & $\% 34,8$ & $\% 39,3$ & $\% 25,9$ & - & - \\
\hline E4. Işletme kararlarında rakiplerin faaliyetleri önemlidir. & $\% 45,6$ & $\% 32,3$ & $\% 11,6$ & $\% 10,5$ & - \\
\hline E5. İşletme kararlarında müşteri beklentileri önemlidir. & $\% 23,6$ & $\% 32,3$ & $\% 28,9$ & $\% 15,2$ & - \\
\hline E6. İşletme kararlarında işletme sahibinin kararı önemlidir. & $\% 50,2$ & $\% 34,5$ & $\% 13,3$ & $\% 2$ & - \\
\hline
\end{tabular}

Araştırma anketinin son bölüm soruları tasarımın işletmenin rekabet düzeyini belirlemedeki rolünü ölçen soruları ölçmek için sorulmuştur. İçerisinde 3 alt maddeden oluşan sorunun yüzdelik dilimleri Tablo 7 de belirtilmiştir. Bu sonuçlara göre, en fazlaya yüzdeye sahip önerme (Kesinlikle Katıliyorum + Katılıyorum) \%84,5 ile ar-ge faaliyetleri içinde yeni teknolojiler geliştirmenin büyük pay vardır önermesidir (Tablo 7, F2). Bu önermenin yüksek çıkması ankete katılan işletmelerin bir kısmının faaliyet alanının otomotiv ve yan sanayi, endüstriyel makine olmasından kaynaklı olabilmektedir. Tasarımda inovasyonun rekabet edebilirlikte \% 46,5 oranında kalması, işletmelerde inovasyon ve ar-ge kültürünün gelişmediğini göstermektedir (Tablo 7, F3). Küresel rekabet edebilirlik raporunda da Türkiye'nin inovasyon ve ar-ge kapasitesinin ortalamanın altında çıkması, bu fikri doğrular niteliktedir. 
Tablo 7. Rekabet Edebilirlik Analiz Sonuçları

\begin{tabular}{|l|l|l|l|l|l|}
\hline F.Rekabet Edebilirlik & $\begin{array}{l}\text { Kesinlikle } \\
\text { Katılıyorum }\end{array}$ & Katılıyorum & $\begin{array}{l}\text { Kısmen } \\
\text { Katılıyorum }\end{array}$ & Katılmıyorum & Fikrim Yok \\
\hline F1.Ar-ge faaliyetleri içinde tasarımın büyük payı vardır. & $\% 23,6$ & $\% 32,3$ & $\% 28,9$ & $\% 15,2$ & - \\
\hline $\begin{array}{l}\text { F2.Ar-ge faaliyetleri içinde yeni teknolojiler geliştirmenin } \\
\text { büyük payı vardır. }\end{array}$ & $\% 45,9$ & $\% 38,6$ & $\% 14,6$ & $\% 0,9$ & - \\
\hline F3.Tasarımda inovasyon rekabet edebilirlikte önemlidir. & $\% 11,9$ & $\% 34,6$ & $\% 36,8$ & $\% 16,7$ & - \\
\hline
\end{tabular}

\section{Sonuçlar ve Öneriler}

$\mathrm{Bu}$ çalışmada mobilya, otomotiv ana/yan sanayi, endüstriyel makine sektörlerinde tasarımın, işletme performansı ve işletmenin başarı ölçütleri olan etkinlik, verimlilik, kârlılık, ekonomiklik üzerinde etkisi araştırılmıştır. Sürekli genişleyen, değişen ve sınırsızlaşmaya doğru giden müşteri talep ve isteklerini karşılamaya çalışan işletmeler, zorlu rekabet koşullarında, rakipleri karşısında üstünlüğü sağlamak, yeniliği yakalamak, işletmelerinin performansını arttırmak için çeşitli stratejiler geliştirmeye başlamışlardır. Tasarımla rekabette bu stratejilerin etkilisi olduğu literatür araştırmalarında da görülmektedir $[12 ; 15 ; 16$; $17 ; 18 ; 19 ; 20 ; 21 ; 22 ; 23 ; 24 ; 25 ; 26$;].

Literatürde rekabet edebilirlik analizlerine bakıldığında, bu rekabet içinde değişime ayak uyduramayan işletmelerin yok olma kaçınılmazlığı, tasarımı stratejik bir unsur olarak kullanılmayı adeta zorunlu hâle getirmektedir. İşletmeleri tasarım doğrultusunda yapılandırmak ve karar verme sürecinde işletmelerin bu unsur doğrultusunda adım atmalarını sağlamak farklılaşmaya giden yolda önemli bir adım olmaktadir.

Yapılan bu çalışma kapsamında tasarımın işletme verilerindeki rolünü değerlendirmek, yerinin ne olduğunu belirlemek için altı boyut ve kırk bir alt boyuttan oluşan ölçek geliştirilmiştir.

Tasarımın işletme performansına etkisini ölçmek araştırmanın temel amacıdır. Literatürde de işletme performansına etkisini araştıran çalışmalarda verimliliğin, kârlılığın ve ekonomikliğin tasarımla ilişkili olduğu ifade edilmektedir $[15 ; 16 ; 17 ; 18]$. Bu açıdan araştırmanın 
temeli olan tasarımın işletme başarısını pozitif olarak etkilediğinin kabul edilmesi ile yapılan araştırma ve ilgili literatürün birbirini destekler nitelikte olduğu görülmektedir.

İşletmeye özgü yeteneklere dayalı bir tasarım stratejisi, rekabet üstünlüğü elde etmede oldukça önemli ölçüde katkı sağlamaktadır. İşletmeler kendi pazar hedefleri ve beklentileri doğrultusunda rekabet üstünlüğü sağlayabilmek için pazarın gereksinimlerini ve tasarım yeteneklerini birleştirerek karar almaları gerekmektedir.

$\mathrm{Bu}$ çalışma kapsamında mobilya, endüstriyel makine ve otomotiv ana/yan sanayi faaliyetlerinde etkinlik gösteren işletmeler $\% 88,5 \mathrm{~s} 1 \mathrm{k}-$ lıkla endüstriyel tasarımın fark yarattığını kabul etmektedirler. \%88,9 sıklıkla üretim kararlarında maliyetin en önemli faktör olduğu, \%84 s1klıkla tasarımın rekabette stratejik bir unsur olduğu, \%84,7 siklıkta tasarımın kârlılığ1 arttırdığı/tasarımın kârlılığının arttığı bulunan sonuçlar arasındadır. Stratejik karar almada işletme sahibinin kararı \%84,7 sıklıkla en önemli faktör olarak ortaya çıkmıştır, bu durum araştırma konusu olan işletmelerin kurumsallaşamadıklarını göstermektedir. Yapılan bu araştırma sadece mobilya, endüstriyel makine, otomotiv ana/yan sanayi alanlarında faaliyet gösteren işletmeler kapsamında uygulanmıştır. Çalışma bu açıdan değerlendirildiğinde elde edilen sonuçların, daha büyük ölçekli işletmelerle yapılan/yapılacak araştırmalarda farklı sonuçlar tespit edilebilir. Öte yandan araştırmada elde edilen bu bulguların farklı sektörlerde tasarım ve üretim faaliyeti gösteren işletmeler için geçerliliği bulunmamaktadır. Bununla birlikte, bu araştırma farklı sektörlerde faaliyet gösteren diğer işletmeler üzerinde benzer araştırmanın gerçekleştirilmesi bakımından rehber niteliği taşıyabilir.

Yapılan araştırmanın sonuçlarına göre Türkiye'de tasarım ve üretim faaliyeti gösteren işletmelerin ar-ge ve tasarım arasındaki ilişkileri bir hayli zayıftır. İşletmelerde ar-ge faaliyetlerine karşı ciddi bir duyarlılığın oluşturulması son derece önemlidir. Bunun için işletmelerin ar-ge teşviklerinden yararlanmayı sağlanmanın yoluna gitmek bir çözüm olabilir. Yapılan bu çalışmada elde edilen sonuçların genel bir 
değerlendirilmesi yapıldığında, endüstriyel ürün tasarımıyla işletme performansını arttırmanın yolu tasarımda küresel ve yerel rekabet düzeyinin yükseltilmesi ile mümkün olabileceği söylenebilir. Küresel anlamda rekabet edilebilirliğin şartının da yüksek katma değerli ürün tasarlamak olduğu açıktır.

İşletmeler için rekabete giden yolda yüksek katma değerli ürün tasarlamanın koşulu da inovasyon ve ar-ge faaliyetlerinin işletmelere entegre edilmesidir. İnovasyon ve ar-ge faaliyetlerinin entegre edilmesinin koşulu da endüstriyel tasarım bilincinin işletmede gelişmesiyle mümkündür.

\section{Kaynaklar}

[1] Gürsu, H. Sahi, inovasyon neden bize bu kadar uzak? İstanbul: Destek Yayınlar1. (2014).

[2] Terhi, H. Hytönen, J. \& Lammi, M. Modelling The Strategic Impacts of Design in Business., (s. 70). (2005).

[3] Caldecote, V. Investment in New Product Development. Journal of Royal Society of Arts. (1979).

[4] Hollins, \& Hollins. Total Design. İngiltere. (1991).

[5] Bruce, M. \& Bessant. Design in Business. Financial Times. (2002).

[6] Küçükerman, P. Ö. 100 Adımda Endüstri için Ürün Tasarlamak. İstanbul: Tofaş Türk Otomotiv Fabrikası A.Ş. (2014).

[7] T.C Gümrük ve Ticaret Bakanlığg. Küresel Rekabetçilik Raporu. Ankara: RYKGM- Ekonomik Analiz ve Değerlendirme Dairesi. (2014-2015).

[8] Porter, M. E. The Competitive Advantage of Nations. Harward Business Review, 73-93. (1990).

[9] Onur, M. Ülkesel Tasarım Stratejilerinin Oluşturulmasında Tasarım Konseylerinin Rolü Ve Önemi. Ankara. (2011).

[10] Schumpeter, Joseph A., 1883-1950. Capitalism, Socialism, and Democracy. New York Harper \& Row, (1962).

[11] BusinessWeek. "Designer Cars”. BusinessWeek, 56-61. (2004).

[12] Economist, T. "Designer Angst”. The Economist, 71-72. (1995).

[13] Potter S. and Walsh, Design Teams on the Rails. In Design Management Journal, Fall, pp. 55-60. (1991). 
[14] Creativity, Design and Business Performance. DTI Economic Papers, s. 22, (2005).

[15] Griffiths, D. Responding to the Economic Downturn. DMI. (2002).

[16] Walsh, V., Roy, R., \& Bruce, M. Competitive by Design. Journal of Marketing Management, 201-216. (1988).

[17] Hertenstein, J. H., Platt, M. B., \& Veryzer, R. W. The Impact of Industrial Design Effectiveness on Corporate Financial Performance. Journal of Product Innovation Management, 22(3), (2005).

[18] Motohashi, K. Innovation Strategy and Business Performance of Japanese. (1998).

[19] Walsh, Roy, Bruce, \& Potter Wining by Design. Oxford: Blackwell. (1992).

[20] Sarasvathy, S. D. Making It Happen: Beyond Theories of the Firm to Theories of Firm Design. Entrepreneurship Theory and Practice. (2004).

[21] Guo, L. Product Design and Financial Performance. The Design Management Institue. (2010).

[22] Riedel, J., Roy, R., \& Potter, S. Design and Market Position-Mapping The Market with The Madrid Market Map. International Product Development Management Conference. Hamburg, Germany. (2008).

[23] Hsu, Y. Comparative Study of Product Design Strategy and Related Design Issues. Journal of Engineering Design, 357-370. (2006).

[24] Choi, Lee, Williams. Innovation and Firm Performance in Korea and China: a cross-context test of mainstream theories. Economics, Computer Science, 25, 423-444, (2013).

[25] Gao, Y., Liu, Z., Song, S., \& Zheng, J. T.echnological Capacity, Product Position, and Firm Competitiveness. The Chinese Economy, 46(1), 55-74. (2013).

[26] Keller, K.L. and Aaker, D.A. The Effects of Sequential Introduction of Brand Extensions. Journal of Marketing Research, 29, 35-50. (1992).

[27] Ma, B., Ed, O., Na, B. A Review on Sample Size Determination for Cronbach's Alpha Test: A Simple Guide for Researchers. Malays J Med Sci. 2018 Nov;25(6):85-99. (2018). 
